\title{
Quality of life evaluation among patients with coronary heart disease at secondary hospital, Yogyakarta
}

\author{
Pramitha Esha Nirmala Dewi*, Zahratul Mulazamah
}

\begin{abstract}
Department of Pharmacy Profession, Faculty of Medicine and Health Sciences, Universitas Muhammadiyah Yogyakarta, Indonesia
\end{abstract}

Received: 03 September 2020

Revised: 08 February 2021

Accepted: 10 February 2021

\section{*Correspondence:}

Dr. Pramitha Esha Nirmala Dewi,

Email: pramithaesha@umy.ac.id

Copyright: (C) the author(s), publisher and licensee Medip Academy. This is an open-access article distributed under the terms of the Creative Commons Attribution Non-Commercial License, which permits unrestricted non-commercial use, distribution, and reproduction in any medium, provided the original work is properly cited.

\begin{abstract}
Background: Coronary heart disease (CHD) is a progressive disease that continues to increase every year in Indonesia so it becomes a problem and a threat to the community. CHD has several factors that affect the quality of life, both in terms of physical, social, psychological, and environmental. The purpose of this research is to illustrate domain WHOQOL-BREFF and SAQ-7 to the quality of life of CHD which is undergoing outpatient at one of Secondary Hospital in Yogyakarta, Indonesia.

Methods: This observational study was involving all patients with CHD who came to the Cardiology Outpatient Department during 4 months study period. There were 90 patients who met with eligibility criteria and willing to participate in the study. The SAQ-7 and WHOQOL-BREFF were used to measure the quality of life among the participants.

Results: Generally, all the participants in this study considered in the high quality of life even they had been diagnosed with CHD. Among all the participants, surprisingly $97 \%$ participants by WHOQOL-BREF and $91 \%$ participants by SAQ-7 reported in the high score of quality of life. The most supported factor for their quality of life defined by WHOQOL-BREF was the Psychological domain with $\mathrm{r}=0.870$ and the Treatment Satisfaction with $\mathrm{r}=0.830$ defined by SAQ-7.

Conclusions: The highest supportive factor for patient's quality of life with carrying CHD were the psychological domain and their treatment satisfaction.
\end{abstract}

Keywords: Coronary heart disease, Quality of life, WHOQOL-BREF, SAQ-7

\section{INTRODUCTION}

The intensity of coronary heart disease in the world is increasing, especially in Indonesia so that it can have an impact on the quality of life of patients. Coronary Heart Disease (CHD) is a disease characterized by symptoms of discomfort in the form of pain in the chest, chest feels heavy, and feels tight when doing activities caused by the buildup of fat plaque. ${ }^{1}$ To prevent the occurrence of attacks again, pharmacological and non-pharmacological therapies can be used which are expected to improve the quality of life of CHD patients when they are on the move. ${ }^{2}$

Changes in lifestyle in CHD patients can cause quite high of anxiety and depression which allow complications and worsening. ${ }^{3}$ This has an impact on changes in the quality of life of CHD patients such as having limitations when doing activities, changing the patterns of diet, work, and treatment processes. ${ }^{4}$ 
According to the World Health Organization Quality of Life (WHOQOL), quality of life is the individual's perception of the position in life with the cultural context and the value of each individual related to the goals, expectations, and standards set by a person. ${ }^{5}$ To find out the physical ability and optimal health status in CHD patients, good quality of life is needed. Measured quality of life can provide benefits in the management of comprehensive and quality therapy for CHD patients. ${ }^{6}$

This study used two questionnaires, namely WHOQOLBREF and SAQ-7. WHOQOL-BREF is a questionnaire that measures the quality of life in general and covers four domains, namely physical, psychological, social, and environmental relationships consisting of 26 questions and translated into Indonesian5. Whereas, SAQ-7 is a special questionnaire to measure the quality of life of $\mathrm{CHD}$ patients in which 7 questions covering five clinical domains, namely physical limitations, the stability of angina, frequency of angina, satisfaction with treatment, and perception of disease. ${ }^{7}$

A lot of research has been done on the quality of life of CHD patients in Indonesia, but it has not been clearly illustrated and there are still few studies describing the quality of life using two questionnaires as well as specifically analyzing the quality of life of CHD patients in the WHOQOL-BREF domain and SAQ-7 domain. Therefore, this study was conducted to find out how the picture and relationship of quality of life in CHD patients at Secondary Hospital in Yogyakarta, so that it can be used as a consideration in taking further treatment steps and making the quality of life of CHD patients improve.

\section{METHODS}

This research was performed as a descriptive study with a cross-sectional design. The study was conducted at Secondary Hospital in Yogyakarta for the period October 2017- February 2018 due to the limited time and budget given by institutional sponsor. This study used purposive sampling with the inclusion criteria to all the CHD patients who visited the Cardiology Outpatient Department Hospital and were willing to fulfil all the question from the questionnaires. This study used 2 instruments for data collection. The instruments included were WHOQOLBREF and SAQ-7 questionnaires. The collected data were analyzed using Pearson's correlation statistical analysis test to find relationships with four WHOQOL-BREF domains and 5 SAQ-7 domains. This study was approved by The Ethics Committee of the Faculty of Medicine and Health Sciences, University of Muhammadiyah Yogyakarta.

\section{RESULTS}

\section{Quality of life evaluation}

The results showed that based on WHOQOL-BREF, most respondents had a high quality of life as many as 87 respondents (97\%) and as many as 3 respondents (3\%) had a low quality of life.

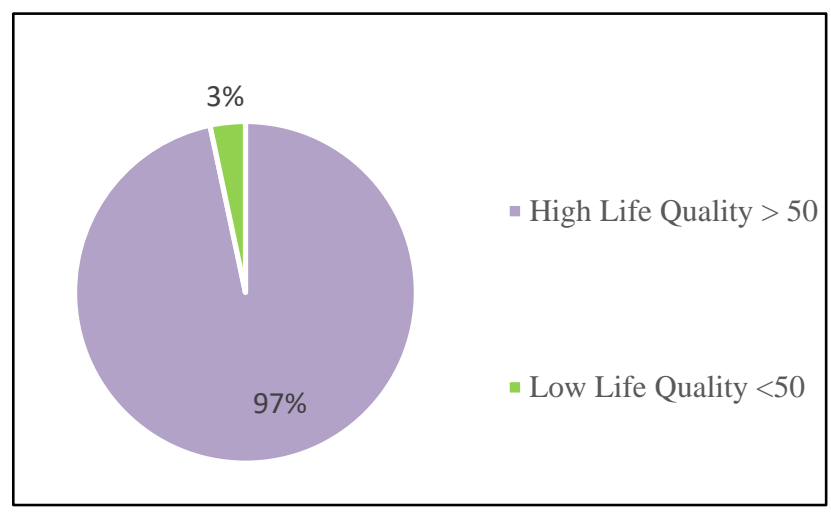

Figure 1: Quality of life of CHD patients based on WHOQOL-BREF.

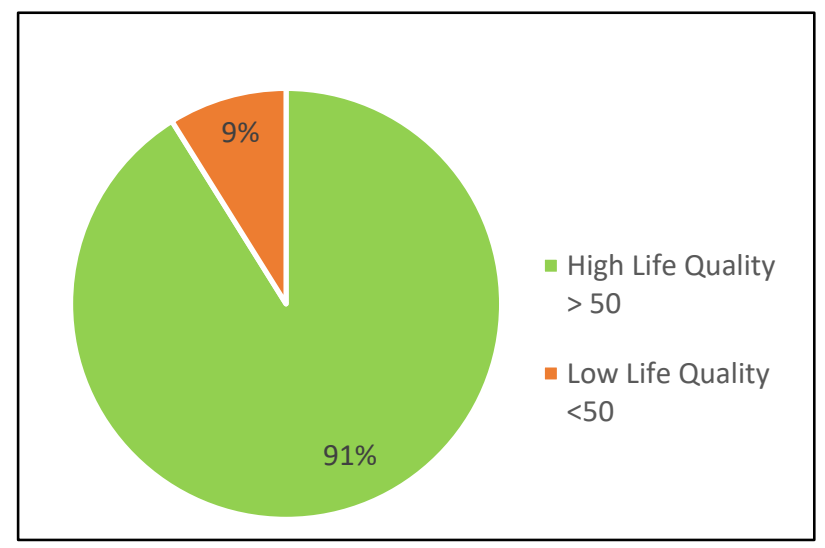

Figure 2: Quality of life of CHD patients based on SAQ.

While the results of research based on SAQ-7 found that most respondents had a high quality of life of 82 respondents $(91 \%)$ and as many as 8 respondents $(9 \%)$ had a low quality of life.

This is in line with the previous study conducted by Kim that most respondents have a high quality of life. ${ }^{8}$ This condition can be attributed to good physical function, good respondent satisfaction in accepting good body conditions, and conditions.

In the previous research in 2011 conducted by Rochmayanti stated that a high quality of life is influenced by age, income, and depression. However, there are still a few respondents who have a low quality of life. ${ }^{9}$ Low quality of life can be caused by physical limitations when doing activities, having a poor assessment of their health and having perceptions that are not in line with what is expected related to CHD.

This can occur due to lack of information and support from the family, environment, and health workers regarding the prognosis of CHD. ${ }^{8}$ 
Analysis of domain relations with the quality of life of CHD patients

This study found that based on WHOQOL-BREF, most respondents had a high quality of life as many as 87 respondents (97\%) and as many as 3 respondents (3\%) had a low quality of life. While the results of research based on SAQ-7 found that most respondents had a high quality of life of 82 respondents $(91 \%)$ and as many as 8 respondents $(9 \%)$ had a low quality of life.

Table 1: Correlation of physical health to quality of life in patients with CHD in Yogyakarta Hospital.

\begin{tabular}{|lllllll|}
\hline & Quality of life & \multicolumn{3}{c|}{ High } & & Total \\
\hline Physical health & Amount & \% & Amount & \% & Amount & $\%$ \\
\hline Not good & 0 & 0 & 0 & 0 & 0 & 0 \\
\hline Good enough & 2 & 2 & 11 & 12 & 13 & 14 \\
\hline Good & 1 & 1 & 74 & 83 & 75 & 84 \\
\hline Very good & 0 & 0 & 2 & 2 & 2 & 2 \\
\hline Total & 3 & 3 & 87 & 97 & 90 & 100 \\
\hline
\end{tabular}

Correlation coefficient $(r)=0.696$; Determination coefficient $\left(r^{2}\right)=0.484$; Significance $(p)=0.000$

Table 2: Psychological relationship to quality of life in patients with CHD in Yogyakarta Hospital.

\begin{tabular}{|lllllll|}
\hline & Quality of life & & & \multicolumn{2}{l|}{ Total } \\
\hline Psychological & Low & & High & & Amount & \% \\
\hline Not good & Amount & $\mathbf{\%}$ & Amount & $\mathbf{\%}$ & 0 & 11 \\
\hline Good enough & 0 & 0 & 0 & 0 & 0 & 41 \\
\hline Good & 3 & 3 & 7 & 8 & 10 & 48 \\
\hline Very good & 0 & 0 & 37 & 41 & 37 & 100 \\
\hline Total & 0 & 0 & 43 & 48 & 43 & 97 \\
\hline
\end{tabular}

Correlation coefficient $(r)=0.870$; Determination coefficient $\left(r^{2}\right)=0.756$; Significance $(p)=0.000$.

Table 3: Social relations on quality of life in patients with CHD in Yogyakarta Hospital.

\begin{tabular}{|c|c|c|c|c|c|c|}
\hline \multirow{3}{*}{ Social relations } & \multicolumn{4}{|c|}{ Quality of life } & \multirow{2}{*}{\multicolumn{2}{|c|}{ Total }} \\
\hline & Low & & High & & & \\
\hline & Amount & $\%$ & Amount & $\%$ & Amount & $\%$ \\
\hline Not good & 0 & 0 & 0 & 0 & 0 & 0 \\
\hline Good enough & 1 & 1 & 0 & 0 & 1 & 1 \\
\hline Good & 2 & 2 & 61 & 68 & 63 & 70 \\
\hline Very good & 0 & 0 & 26 & 29 & 26 & 29 \\
\hline Total & 3 & 3 & 87 & 97 & 90 & 100 \\
\hline
\end{tabular}

Correlation coefficient $(r)=0.730$; Determination coefficient $\left(r^{2}\right)=0.533$; Significance $(p)=0.000$

Table 4: Environmental relationship to quality of life in patients with CHD in Yogyakarta Hospital.

\begin{tabular}{|c|c|c|c|c|c|c|}
\hline \multirow{3}{*}{ Environment } & \multicolumn{4}{|c|}{ Quality of life } & \multirow{2}{*}{\multicolumn{2}{|c|}{ Total }} \\
\hline & \multicolumn{2}{|l|}{ Low } & \multicolumn{2}{|l|}{ High } & & \\
\hline & Amount & $\%$ & Amount & $\%$ & Amount & $\%$ \\
\hline Not good & 0 & 0 & 0 & 0 & 0 & 0 \\
\hline Good enough & 0 & 0 & 1 & 1 & 1 & 1 \\
\hline Good & 3 & 3 & 44 & 49 & 47 & 52 \\
\hline Very good & 0 & 0 & 42 & 47 & 42 & 47 \\
\hline Total & 3 & 0 & 87 & 97 & 90 & 100 \\
\hline
\end{tabular}

Correlation coefficient $(r)=0.799$; Determination coefficient $\left(r^{2}\right)=0.638$; Significance $(p)=0.000$

\section{WHOQOL-BREF}

\section{Physical Health}

Table 1 shows the value of $\mathrm{p}=0.000$ which means that Ho is rejected and $\mathrm{H} 1$ is accepted so that there is a physical health effect on the quality of life of CHD patients with the closeness of the relationship has a correlation level $\mathrm{r}=0.694$, while $\mathrm{r} 2=0.484$. This shows that $48.4 \%$ of physical factors affect the quality of life of CHD. 


\section{Psychological}

Table 2 shows the value of $\mathrm{p}=0.000$, which means that Ho is rejected and $\mathrm{H} 1$ is accepted so that there is a psychological influence on the quality of life of CHD patients with the closeness of the relationship has a level of correlation $\mathrm{r}=0.870$, while $\mathrm{r} 2=0.756$. This shows that $75.6 \%$ psychologically affects the quality of life of CHD.

\section{Social Relations}

Table 3 shows the value of $\mathrm{p}=0.000$, which means that Ho is rejected and $\mathrm{H} 1$ is accepted so that there is an influence of social relations on the quality of life of CHD patients with the closeness of the relationship has a correlation level $\mathrm{r}=0.730$, while $\mathrm{r} 2=0.533$. This shows that $53.3 \%$ of social relations affect the quality of life of CHD.

Table 5: Correlation between physical limitations on quality of life in patients with CHD in Yogyakarta Hospital.

\begin{tabular}{|c|c|c|c|c|c|c|}
\hline \multirow{3}{*}{ Physical limitations } & \multicolumn{4}{|c|}{ Quality of life } & \multirow{2}{*}{\multicolumn{2}{|c|}{ Total }} \\
\hline & Low & & High & & & \\
\hline & Amount & $\%$ & Amount & $\%$ & Amount & $\%$ \\
\hline Very heavy & 0 & 0 & 0 & 0 & 0 & 0 \\
\hline Heavy & 2 & 2 & 6 & 7 & 8 & 9 \\
\hline Medium & 5 & 5 & 34 & 38 & 39 & 43 \\
\hline Light & 2 & 2 & 41 & 46 & 43 & 48 \\
\hline Total & 9 & 9 & 81 & 91 & 90 & 100 \\
\hline
\end{tabular}

Correlation coefficient $(r)=0.362$; Determination coefficient $\left(r^{2}\right)=0.131$; Significance $(p)=0.000$

Table 6: Correlation between angina stability and quality of life in patients with CHD in Jogja Hospital.

\begin{tabular}{|c|c|c|c|c|c|c|}
\hline \multirow{3}{*}{ Angina stability } & \multicolumn{4}{|c|}{ Quality of life } & \multirow{2}{*}{\multicolumn{2}{|c|}{ Total }} \\
\hline & Low & & High & & & \\
\hline & Amount & $\%$ & Amount & $\%$ & Amount & $\%$ \\
\hline Not good & 3 & 4 & 1 & 1 & 4 & 5 \\
\hline Good enough & 1 & 1 & 2 & 2 & 3 & 3 \\
\hline Good & 3 & 3 & 5 & 6 & 8 & 9 \\
\hline Very good & 1 & 1 & 74 & 82 & 75 & 83 \\
\hline Total & 8 & 9 & 82 & 91 & 90 & 100 \\
\hline
\end{tabular}

Correlation coefficient $(r)=0.757$; Determination coefficient $\left(r^{2}\right)=0.573$; Significance $(p)=0.000$

Table 7: Correlation of the frequency of angina to quality of life in patients with CHD in Yogyakarta Hospital.

\begin{tabular}{|c|c|c|c|c|c|c|}
\hline \multirow{3}{*}{ Angina frequency } & \multicolumn{4}{|c|}{ Quality of life } & \multirow{2}{*}{\multicolumn{2}{|c|}{ Total }} \\
\hline & \multicolumn{2}{|l|}{ Low } & \multicolumn{2}{|l|}{ High } & & \\
\hline & Amount & $\%$ & Amount & $\%$ & Amount & $\%$ \\
\hline Very often & 4 & 5 & 0 & 0 & 4 & 5 \\
\hline Often & 2 & 2 & 1 & 1 & 3 & 3 \\
\hline Rare & 0 & 0 & 2 & 2 & 2 & 2 \\
\hline Very rarely & 2 & 2 & 79 & 88 & 81 & 90 \\
\hline Total & 8 & 9 & 82 & 91 & 90 & 100 \\
\hline
\end{tabular}

Correlation coefficient $(r)=0.806$; Determination coefficient $\left(r^{2}\right)=0.650$; Significance $(p)=0.000$

Table 8: Correlation between treatment satisfaction and quality of life in patients with CHD in Yogyakarta Hospital.

\begin{tabular}{|c|c|c|c|c|c|c|}
\hline \multirow{3}{*}{ Treatment satisfaction } & \multicolumn{4}{|c|}{ Quality of life } & \multirow{2}{*}{\multicolumn{2}{|c|}{ Total }} \\
\hline & \multicolumn{2}{|l|}{ Low } & \multicolumn{2}{|l|}{ High } & & \\
\hline & Amount & $\%$ & Amount & $\%$ & Amount & $\%$ \\
\hline Very dissatisfied & 1 & 1 & 0 & 0 & 1 & 1 \\
\hline Not satisfied & 5 & 6 & 4 & 5 & 9 & 11 \\
\hline Satisfied & 2 & 2 & 13 & 14 & 15 & 16 \\
\hline Very satisfied & 0 & 0 & 65 & 72 & 65 & 72 \\
\hline Total & 8 & 9 & 82 & 91 & 90 & 100 \\
\hline
\end{tabular}

Correlation coefficient $(r)=0.830$; Determination coefficient $\left(r^{2}\right)=0.689$; Significance $(p)=0.000$ 
Table 9: Correlation of perceptions on diseases of quality of life in patients with CHD in Yogyakarta Hospital.

\begin{tabular}{|c|c|c|c|c|c|c|}
\hline \multirow{3}{*}{ Perception of disease } & \multicolumn{4}{|c|}{ Quality of life } & \multirow{2}{*}{\multicolumn{2}{|c|}{ Total }} \\
\hline & \multicolumn{2}{|c|}{ Low } & \multicolumn{2}{|l|}{ High } & & \\
\hline & Amount & $\%$ & Amount & $\%$ & Amount & $\%$ \\
\hline Very bad & 1 & 1 & 2 & 2 & 3 & 3 \\
\hline Bad & 4 & 5 & 20 & 19 & 24 & 24 \\
\hline Good & 3 & 3 & 43 & 48 & 46 & 51 \\
\hline Very good & 0 & 0 & 17 & 22 & 17 & 22 \\
\hline Total & 8 & 9 & 82 & 91 & 90 & 100 \\
\hline
\end{tabular}

Correlation coefficient $(r)=0.634$; Determination coefficient $(r 2)=0.402$; Significance $(p)=0.000$

\section{Environment}

Table 4 shows the value of $\mathrm{p}=0.000$ which means that Ho is rejected and $\mathrm{H} 1$ is accepted so that there is an environmental influence on the quality of life of CHD patients with the closeness of the relationship has a level of correlation $\mathrm{r}=0.799$, while $\mathrm{r} 2=0.638$. This shows that $63.8 \%$ of environmental factors affect the quality of life of CHD.

\section{$S A Q$}

\section{Physical limitations}

Table 5 shows the value of $\mathrm{p}=0.000$ which means that Ho is rejected and $\mathrm{H} 1$ is accepted so that there is an effect of physical limitations on the quality of life of CHD patients with the closeness of the relationship has a correlation level $\mathrm{r}=0.362$, while $\mathrm{r} 2=0.131$. This shows that $13.1 \%$ of physical limitations affect the quality of life of CHD.

\section{Angina stability}

Table 6 shows $\mathrm{p}=0.000$ which means that Ho is rejected and $\mathrm{H} 1$ is accepted so that there is an effect of angina stability on the quality of life of CHD patients with the closeness of the relationship has a correlation level $r=0.757$, while $r 2=0.573$. This shows that $57.3 \%$ of the stability of angina affects the quality of life of CHD.

\section{Angina frequency}

Table 7 shows the value of $\mathrm{p}=0.000$, which means that Ho is rejected and $\mathrm{H} 1$ is accepted so that there is an effect of the frequency of angina on the quality of life of CHD patients with the closeness of the relationship has a correlation level $r=0.806$, while $r 2=0.650$. This shows that $65 \%$ of the frequency of angina affects the quality of life of CHD.

\section{Treatment satisfaction}

Table 8 shows the value of $\mathrm{p}=0.000$ which means that Ho is rejected and $\mathrm{H} 1$ is accepted so that there is an effect of treatment satisfaction on the quality of life of CHD patients with the closeness of the relationship has a level of correlation $\mathrm{r}=0.830$, while $\mathrm{r} 2=0.689$. This shows that
$68.9 \%$ of treatment satisfaction affects the quality of life of CHD.

\section{Perception of disease}

Table 9 shows the value of $\mathrm{p}=0.000$ which means that Ho is rejected and $\mathrm{H} 1$ is accepted so that there is an influence of perception on the disease on the quality of life of CHD patients with the closeness of the relationship has a level of correlation $r=0.634$, while $r 2=0.402$. This shows that $68.9 \%$ of perceptions of the disease affect the quality of life of CHD.

\section{DISCUSSION}

A total of 90 respondents met the inclusion criteria in this study. The majority respondents with CHD were $68 \%$ male. The highest number of patients with $\mathrm{CHD}$ was in age range $61-70$ years old, as many as $38 \%$ respondents. Theoretically presented by some experts that in the higher age, the risk of developing CHD is increasing. This is comparable to the research conducted by Nuraeni, et al where most CHD patients were over 45 years of age $(91 \%) .{ }^{10}$ At the age of more than 45 years, people are at high risk for plaque formation, especially for those who have a positive family history of coronary artery disease. ${ }^{11}$

Regarding gender concern according to CHD prevalence, male morbidity is more than women who have not experienced of menopause period. Female was influenced by estrogen which can protect them from CHD. ${ }^{12}$ This study was found that $48 \%$ respondents had CHD during 15 years. This percentage is in accordance with the previous study which stated that the length of CHD experienced by the average of 3 years. In relation with the disease duration, patients who experience CHD in a longer time will have better self-efficacy. ${ }^{13}$

This study found that based on WHOQOL-BREF, most respondents had a high quality of life as many as 87 respondents (97\%) and as many as 3 respondents (3\%) had a low quality of life. While the results of research based on SAQ-7 found that most respondents had a high quality of life of 82 respondents $(91 \%)$ and as many as 8 respondents (9\%) had a low quality of life. A Study performed by Bagheri, et al mentioned that most respondents have a high quality of life due to their good physical function, good 
respondent satisfaction in accepting good body conditions, and conditions. ${ }^{14}$

Previous study stated that a high quality of life is influenced by age, income, and depression. However, there are still a few patients who have a chronic diseases especially CHD by also having a high quality of life. ${ }^{9}$ Low quality of life can be caused by physical limitations when doing activities, having a poor assessment of their health, and having perceptions that are not in line with what is expected related to CHD. This condition can occur due to the lack of information and support from the family, environment, and health workers regarding the prognosis of CHD. ${ }^{8}$ The environmental domain is a feature of the place where patients live in and their roles in life. The environmental domain can be seen from three aspects such as patient's access to health services, living conditions and financial status. ${ }^{15}$ Residential environment and comfort in getting good health services are needed by CHD patients so that the quality of life of CHD patients improves.

The physical health domain from WHOQOL-BREF, which includes mobility and activity shows that the quality of life is very influential so that it can describe the difficulty level of patients in carrying out their own body in daily activities. The improved physical function is referring to the patients who are still working, getting married, doing good activities, and undergoing rehabilitation, can produce a high quality of life in CHD patients. ${ }^{16}$ This study revealed that CHD patients with physical problems was affecting $48.4 \%$ of their quality of life.

The psychological domain has a strong impact to the patients due to the lifelong medication or medical treatment to reduce their clinical problem such as chest pain, pallor, and shortness of breath while undergoing physical activity which has a psychological impact, as many as $75,6 \%$ impacted to the CHD patient's quality of life. A study conducted by Zamani et al. in 2016 which states that increased physical activity has an influence on the psychological domain such as "always trying to think positively" so they can reach the higher level of selfconfidence in optimizing their body abilities. ${ }^{17}$

The support provided by spouses, children, and friends could also influence their social domain. ${ }^{18}$ In the study conducted by Moser et al. in 2007 stated that lack of social relations can accelerate the risk of heart failure. ${ }^{19}$ Previous study also reported that the well maintained of social relation among the elderly patients could give them a benefit in keeping their good quality of life. ${ }^{9}$ This study reported that $53.3 \%$ of patient's quality of life was impacted by social relations domain.

The environmental domain is a feature of the place where patients live in and their roles in life. The environmental domain can be seen from three aspects such as patient's access to health services, living conditions and financial status. ${ }^{15}$ Residential environment and comfort in getting good health services are needed by CHD patients as its
$63.8 \%$ implication to the quality of life improvement among the CHD patients.

Based on the SAQ questionnaire, the higher the quality of life, the lower physical limitations because physical activity is one of the factors that can trigger chest pain. ${ }^{20}$ Physical limitations can also be affected by the amount of vessels blockage experienced by patients, if the frequency of blockages that occur is greater, the physical limitations will be higher and the quality of life will be lower. ${ }^{21}$ Nevertheless, this study reported only $13.1 \%$ of this domain could affect respondent's quality of life. A study found that the eagerness degree in each person is related to their physical ability and according to the requirement for gaining the good health. ${ }^{22}$

Stable angina can be influenced by respondent compliance in treatment and respondent's awareness to maintain and reduce activities or activities that can trigger symptoms. ${ }^{23}$ Arnold et al stated that angina frequency domains have consistency in supporting the continuation of relevant clinical therapies to reduce angina and improve quality of life. ${ }^{7}$ In accordance with this study findings that the stability and frequency of angina could impact the patient's quality of life as many as $57.3 \%$ and $65 \%$ respectively.

This study found that the quality of life among the CHD patients was dominantly affected by patient's satisfaction regarding the treatment received and perception about their disease. Low treatment satisfaction can be influenced by boredom in consuming drugs. ${ }^{24}$ Bad perceptions can occur due to the lack of information or support from patient's family, environment, and health workers related to the prognosis of CHD. ${ }^{25}$

\section{CONCLUSION}

Based on the results of the study, it can be concluded that the majority of CHD patients at Secondary Hospital in Yogyakarta have a high quality of life in average both defined by the four WHOQOL-BREFF domains (97\%) and five SAQ domains (91\%). The highest supportive factor for their quality of life with carrying CHD on their body was the psychological domain and their treatment satisfaction.

\section{ACKNOWLEDGEMENTS}

The authors gratefully acknowledge the full funding from Universitas Muhammadiyah Yogyakarta.

\section{Funding: No funding sources \\ Conflict of interest: None declared \\ Ethical approval: The study was approved by the Institutional Ethics Committee}

\section{REFERENCES}

1. Depkes. Pharmaceutical care untuk pasien penyakit jantung koroner : fokus sindrom koroner akut. 2014. 
2. Günal WRMA, Gehlmann HR, Luijten JE, Bos JS, Verheugt FWA. Outcome and quality of life one year after percutaneous coronary interventions in octogenarians. Netherlands Heart J. 2008;16.

3. Huffman JC, Stern TA. Neuropsychiatric consequences of cardiovascular medications. Dialog Clin Neurosci. 2007;9(1):29-45.

4. Panthee B. Review: Anxiety and Quality of life in Patients with Myocardial Infarction. J Nurs. 2011;1:105-15.

5. Skevington SM, Lotfy M Fau - O'Connell KA, O'Connell KA. The World Health Organization's WHOQOL-BREF quality of life assessment: psychometric properties and results of the international field trial. A report from the WHOQOL group. 0962-9343.

6. Hutagalung RU. The Quality of Life of Patient with Post Percutaneous Coronary Intervention. Jurnal Keperawatan Padjadjaran. 2014;2.

7. Arnold SV, Kosiborod M, Li Y. Comparison of the Seattle Angina Questionnaire With Daily Angina Diary in the TERISA Clinical Trial. Circ Cardiovasc Qual Outcomes. 2014;7(6):844-50.

8. Kim HS, Kim HK, Kang KO. Determinants of healthrelated quality of life among outpatients with acute coronary artery disease after percutaneous coronary intervention. Jpn J Nurs Sci. 2019;16(1):3-16.

9. Rochmayanti. Analisis Faktor-Faktor Yang Mempengaruhi Kualitas Hidup Pasien Penyakit Jantung Koroner Di Rumah Sakit. 2011.

10. Nuraeni A, Mirwanti R, Iskandar A. Faktor yang Memengaruhi Kualitas Hidup Pasien dengan Penyakit Jantung Koroner. Jurnal Keperawatan Padjadjaran. $2017 ; 4$.

11. Hughes CM. Medication non-adherence in the elderly: How big is the problem? Drugs and Aging. 2004;21(12):793-811.

12. Gupta T, Kolte D, Khera S. Contemporary Sex-Based Differences by Age in Presenting Characteristics, Use of an Early Invasive Strategy, and Inhospital Mortality in Patients with Non-ST-Segment-Elevation Myocardial Infarction in the United States. Circulation: Cardiovascular Interventions. 2018;11(1).

13. Lau-Walker M. Importance of illness beliefs and selfefficacy for patients with coronary heart disease. Journal of advanced nursing. 2007;60:187-98.

14. Bagheri H, Memarian R, Alhani F. Evaluation of the effect of group counselling on post myocardial infarction patients: determined by an analysis of quality of life. J Clin Nurs. 2007;16(2):402-6.

15. Henriksson $\mathrm{C}$, Larsson $\mathrm{M}$, Herlitz $\mathrm{J}$. Influence of health-related quality of life on time from symptom onset to hospital arrival and the risk of readmission in patients with myocardial infarction. Open Heart. 2014;1(1).

16. Christian AH, Cheema Af Fau - Smith SC, Smith Sc Fau - Mosca L. Predictors of quality of life among women with coronary heart disease. 0962-9343.

17. Zamani Sani SH, Fathirezaie Z, Brand S. Physical activity and self-esteem: testing direct and indirect relationships associated with psychological and physical mechanisms. Neuropsychiatr Dis Treat. 2016;12:2617-25.

18. Bosworth HB. Enhancing medication adherence: The public health dilemma. 2012.

19. Moser D, Riegel B, McKinley S. Impact of Anxiety and Perceived Control on In-Hospital Complications After Acute Myocardial Infarction. Psychosomatic medicine. 2007;69:10-6.

20. Min JK, Gilmore A, Jones EC. Cost-effectiveness of diagnostic evaluation strategies for individuals with stable chest pain syndrome and suspected coronary artery disease. Clinical Imaging. 2017;43:97-105.

21. Abdallah MS, Wang K, Magnuson EA. Quality of life after PCI vs CABG among patients with diabetes and multivessel coronary artery disease: a randomized clinical trial. JAMA 2013;310(15):1581-90.

22. Mikalsen HK, Lagestad P, Bentzen M. Does Eagerness for Physical Activity Matter? The Association Between Eagerness and Physical Activity Among Adolescents. Front Public Health. 2019;7:8888.

23. Solomon MD, Go AS, Shilane D, et al. Comparative effectiveness of clopidogrel in medically managed patients with unstable angina and non-ST-segment elevation myocardial infarction. Journal of the American College of Cardiology. 2014;63(21):224957.

24. Weeks G, George J, Maclure K. Non-medical prescribing versus medical prescribing for acute and chronic disease management in primary and secondary care. Cochrane Database of Systematic Reviews. 2016;2016(11).

25. Scardi S, Mazzone C, Di Lenarda A. Adherence to cardioprotective medications in coronary heart disease. Giornale Italiano di Cardiologia. 2009; 10(4):241-48.

Cite this article as: Dewi PEN, Mulazamah Z. Quality of life evaluation among patients with coronary heart disease at secondary hospital, Yogyakarta. Int J Basic Clin Pharmacol 2021;10:220-6. 